\title{
Public Financial Analysis in the Preparation of Indonesia State Budget (APBN) 2018
}

\author{
Cucun Ahmad Syamsurijal ${ }^{1}$ \\ The House of Representatives of the Republic of Indonesia - Indonesia
}

\begin{abstract}
In Indonesia, the function of the budget is carried out by the government as a branch of executive power in charge of preparing the draft of State Budget and Revenue (R-APBN), together with the House of Representatives of the Republic of Indonesia (DPR-RI) as a branch of legislative power in charge of participating in discussing and approving the R-APBN, including oversight of the implementation of the State Budget and Revenue (APBN). During the initial observation process and the results of interviews conducted, the author found several indications of problems relating to the State Budget of the Republic of Indonesia in 2018, such as not all the components are on time so that a delay can affect the existing cycle and The attraction of interests that can not be avoided starting from the interests of groups as well as individual interests. Based on the results of research on the analysis of Public Finance in the preparation of the State Budget (APBN) of the Republic of Indonesia in 2018, it can be concluded The existence of a time delay in the realization of the discussion schedule for the Draft Bill on the 2018 APBN has affected the existing cycle.
\end{abstract}

Keywords: state budget and revenue, legislative

\footnotetext{
${ }^{1}$ Cucun Ahmad Syamsurijal is the Chairman of Partai Kebangkitan Bangsa Faction, The House of Representatives of the Republic of Indonesia. E-Mail: cucun_gsm@yahoo.com
} 


\title{
Public Financial Analysis in the Preparation of State Budget (APBN) 2018 of the Republic of Indonesia
}

\author{
Cucun Ahmad Syamsurijal
}

\section{Introduction}

\subsection{Background}

The state today's world perspective cannot be separated from a sovereign territory that has a set of rules for all individuals in it and is organized by the government which functions to serve the public interest (public interest) effectively and efficiently. In an effort to organize all aspects related to the public interest, governance in a democratic country always applies the principle of checks and balances where power does not lie only on one party as happened in the authoritarian government system, but power is distributed to the Government, Parliament and Judiciary/judiciary to avoid absolute power in the body of the ruler

In Indonesia, the function of the budget is carried out by the government as a branch of executive power in charge of preparing the draft of State Budget and Revenue (R-APBN), together with the House of Representatives of the Republic of Indonesia (DPR-RI) as a branch of legislative power in charge of participating in discussing and approving the R-APBN, including oversight of the implementation of the State Budget and Revenue (APBN). The APBN is not only about economic decisions but also political decisions, therefore the DPR must be able to play an active role in overseeing the APBN so that the APBN can be effective as the main tool for the welfare of the people. Provisions regarding the procedures for preparing the APBN are contained in UUD 1945 article 23 which states that :

1) The State Revenue and Expenditure Budget (APBN) as a form of state financial management is stipulated annually by law and carried out openly and responsibly for the greatest prosperity of the people.

2) The draft National Budget for Income and Expenditure has been proposed by the President to be discussed with the DPR by considering the DPR.

3) If the DPR does not approve the RAPBN proposed by the President, the government will run the State Budget last year.

The Budget Agency (Badan Anggaran) DPR RI is an instrument of the council that has the authority to discuss drafting the state budget with the government. Article 110 paragraph (1) of Law No. 17 of 2014 on the People's Consultative Assembly (MPR), the House of Representatives (DPR), Regional Representative Council (DPD), and the District House of Representatives (DPRD) explaining the work of the Budget Agency DPR RI, including :

a) discuss with the Government represented by the minister to determine the main points of fiscal policy in general and budget priorities to be used as a reference for each ministry/institution in preparing budget proposals;

b) determine state revenue together with the Government with reference to the relevant commission proposal;

c) discuss the draft law about APBN with the President which can be represented by the minister regarding budget allocations for the functions and programs of the Government and regional fund allocation transfers by referring to the decision of the commission and Government working meetings; 
d) synchronize the results of discussions in the commission and other DPR equipment regarding the work plan and budget of the ministry/agency;

e) synchronize the proposed electoral development program proposed by the commission;

f) discuss the realization report and estimated realization related to the APBN; and

g) discussing the main points of explanation of the draft law on accountability for the implementation of the State Budget.

The discussion of the APBN in the DPR is a very complex process considering that the discussion of the APBN involves various parties between the government and the DPR. The DPR Budget Board conducts discussions with the government after the State Budget Draft and financial notes are submitted to the DPR every August 16. At this stage, preliminary discussions with Commission VII and Commission XI discuss macro assumptions. The budget agency will form working groups that will discuss in more detail. Panja membership comes from the government agency's designated budget agency at the work meeting. The results of the Working Committee are then discussed and ratified in the working meetings of the budget agency and government after the commission has discussed the improvement of the Draft State Budget which includes the scope of its duties then synchronizes it simultaneously, namely: 1) The Commission submits the results of the discussion that proposes the improvement of the Draft State Budget which includes the scope of its work; 2) The budget agency synchronizes, then the results are submitted to the commission for further refinement; 3) The results of the refinement of the commission are then returned to the budget agencies for resynchronization; 4) The results of this synchronization are then conveyed by the budget agency in the plenary meeting of decision making on the RUU APBN and its financial memorandum.

In accordance with the mandate of Law 17/2003 on State Finances, discussion of the Draft Bill on the State Budget can begin on the fourth week of August and is stipulated in a plenary session no later than 2 months before the fiscal year starts, namely on the fourth week of October in accordance with Article 15 paragraph 4 of the Law on State Finance. So, in this case, the DPR drew up a planned discussion schedule to run effectively. Following is the 2018 APBN Discussion Cycle Chart in the DPR RI Budget Board. 

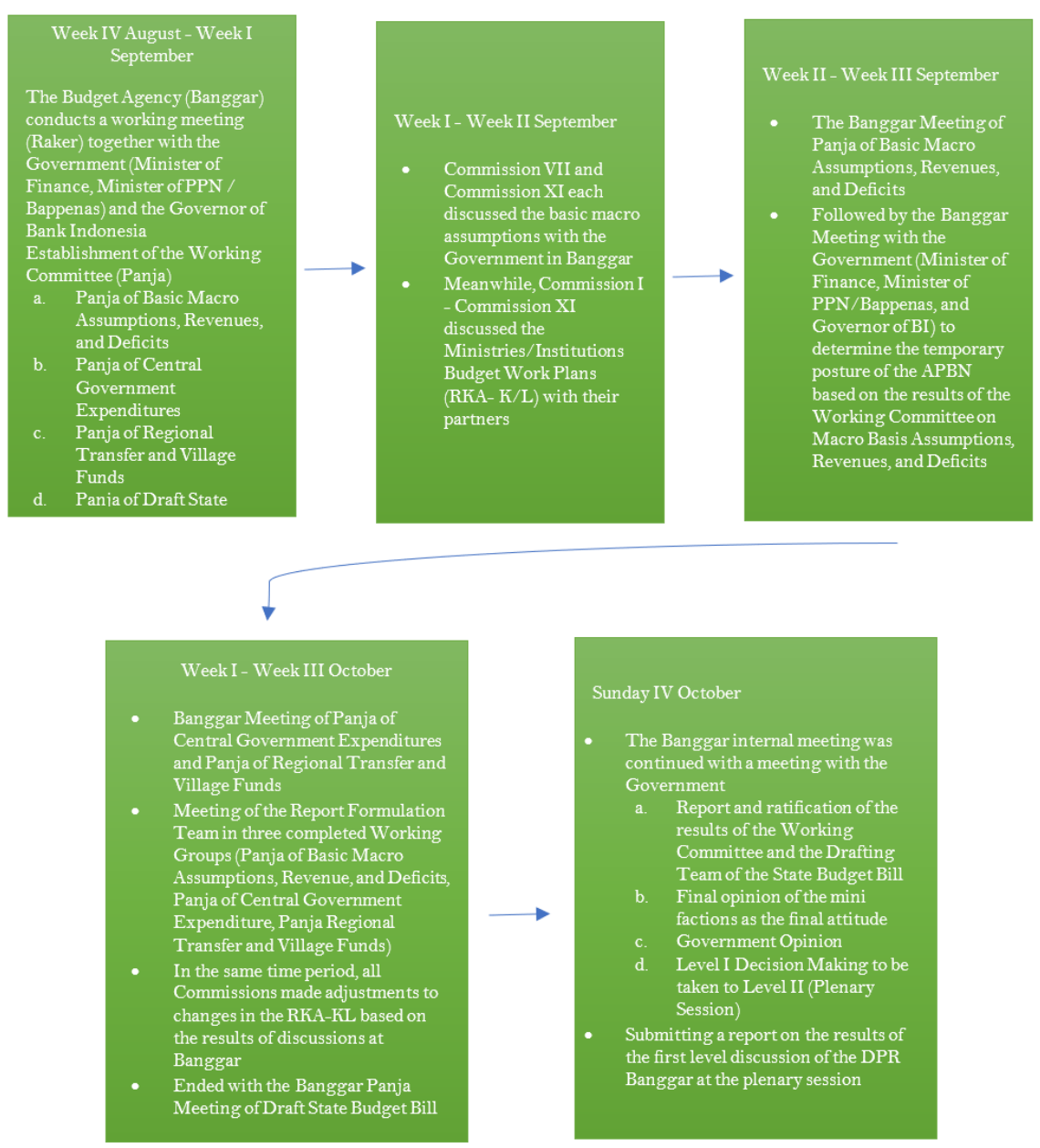

Figure 1. 2018 APBN Discussion Cycle in the DPR RI Budget Board

Source: Adapted from the DPR RI Budget Agency Report on Level I Talks / Discussion of Draft Law on the State Budget

During the initial observation process and the results of interviews conducted, the author found several indications of problems relating to the State Budget of the Republic of Indonesia in 2018, including

1) Not all the components are on time so that a delay can affect the existing cycle. The setback began with an inaccurate meeting of Commissions VI, VII and XI with work partners who retreated for up to 2 days and Meetings of Commissions I to XI were delayed for up to 7 days, causing the Budget Board Meeting with the Government and the BI Governor to be forced to resign for 8 days from set time. The meeting has a strategic value in the cycle of determining the RUU APBN because the meeting will produce a Provisional Posture on the 2018 APBN Bill.

2) The attraction of interests that can not be avoided starting from the interests of groups as well as individual interests. According to data from the Brief Report of the Commission VII Work Meeting of the Republic of Indonesia with the Minister of Energy and Mineral Resources of the Republic of Indonesia on 
Thursday, September 7, 2017, there was a tug of interest from the Government and the Parliament. Conclusion/decision in the first point of the report states that the House of Representatives Commission VII agreed with the Minister of Energy and Mineral Resources to discuss in more detail the basic assumptions of the macro-economy R-APBN 2018 in the Hearing Meeting (RDP) with echelon I of the Ministry of Energy and Mineral Resources. This long debate was more due to the Parliament asking the Government to calculate more carefully and thoroughly given the complexity of the discussion in the area of the basic assumptions in commission VII relating to Crude Oil Prices (ICP) and Oil and Gas Lifting. Therefore, the process of finding this deliberation point has a number of separate consequences.

However, the interests that exist in the discussion cycle of the RUU on APBN cannot be avoided, considering that the DPR as a state political institution that seeks to fight for all the interests of the people must have its own dilemma, and is not infrequently forced to compromise with the situation even though it is not in line with the expectations that are believed. But besides all that, the DPR through the Budget Board needs to pay attention to how the implementation of the RUU APBN discussion can run effectively and efficiently for the sake of justice for the entire Indonesian nation.

\subsection{Research Question}

Based on the above, it is relevant to conduct research on the effectiveness of the Budget Agencies, and present it with the title "Public Financial Analysis in the Compilation of the State Budget (2018). Based on the background of the research described above, the authors formulated that the process of drafting Budget Revenue Expenditure (APBN) so far has not been effective. So the authors submit a research question that is "What is the process of preparing the 2018 State Budget of the Republic of Indonesia by the House of Representatives of the Republic of Indonesia?" This research was conducted to develop the concept of public financial analysis in the preparation of the State Expenditure Budget in Indonesia.

\section{Literature Review}

\subsection{Literature Review \\ 2.1.1. Public Sector Budget}

A public sector budget is a place for the government to provide public services in order to be able to meet public needs in order to prioritize the welfare of the community. The public sector organizes its activities and works programs in a budget. The concept of the budget referred to in this study is the concept of the public sector budget. The budget in the public sector has the same function as the budget in a company, as a statement about the work plan that will be implemented. The public sector budget is a breakdown of all activities to be carried out which are composed of revenue and expenditure plans within one year. The public sector budget is made to facilitate the government in determining the level of community needs such as electricity, clean water, health quality, and education in order to improve the welfare of the community will be more secure, as well as more effective use and allocation.

According to Mardiasmo, there are several reasons why the public sector budget becomes important, namely the budget as a determinant of the needs and desires of the community. The budget is a government tool to direct socio-economic development, ensure sustainability, and improve the quality of life of the people.

The Indonesian Journal of Development Planning

Volume III No. 2 - August 2019 
According to Ibnu Syamsi, the state budget is the result of a plan in the form of a list of various integrated activities, both regarding its revenues and expenditures expressed in units of money within a certain period of time. The Unitary State of the Republic of Indonesia establishes its state budget in The State Revenue and Expenditure Budget (APBN) is set every year by law after obtaining approval from the House of Representatives.

\subsubsection{Types and Approaches of Government Budgets}

According to Mardiasmo (2002: 66) revealed that the government budget can be divided into two groups, namely:

1) Operational Budget

2) Capital / Investment Budget

In addition, there are several types of approaches in planning and preparing government budgets. Mardiasmo (2002: 75) revealed that there are several types of approaches in planning that in general there are two main approaches that have fundamental differences, namely;

1) Traditional Budget (Conventional Budget) The characteristics of this approach include:

a) How to prepare a budget based on the incrementalism approach.

b) Line item structure and budget formulation

c) Tends to be centralized

d) Specific

e) Annual

f) Using the principle of gross budget

2) New Public Management (NPM), which became known in the 1980 s and became popular in the 1990 s.

Planning in preparing a budget is very important. However, it is clear what will be done in the future. Strategic thinking in every organization is the process of management thinking about integrating organizational activities towards goals that are oriented towards future goals. The more volatile the market environment, technology or the external economy, the management will be encouraged to develop strategies. Management strategic thinking realized in various plans, and the overall integration process is supported by organizational budgeting procedures.

Based on the description above it can be concluded that the budget is a financial plan which is an estimate of what will be done in the future. Each expenditure budget outlines various specific facts about what is planned to be done by the organizational unit that compiles the budget in the future time period. In the budget, it is explained that there are expenditure plans based on income expectations. Expenditure plans should also indicate the order of priority scale and expectations of service quality and quantity. All government expenditure and revenue plans are carried out through discussion procedures by the legislature to be approved annually, on-budget. Also, a small portion of the budget financed with a dedicated fund is not discussed by the legislature every year, off-budget. An example of off-budget is the allocation of funds intended for pension programs and old-age benefits.

\subsubsection{Principles of Public Sector Budgeting}

Many things become the principle of general budgeting, but there are several principles used in public sector budgeting namely: 
1. Authorization by the legislature: the budget must get authorization from the legislature before the executive can spend it.

2. Comprehensive: the budget can show all government requests and expenses.

3. Budget integrity: all government revenues and expenditures must be collected in public funds based on priorities and principles of expenditure.

4. Nondiscretionary Appropriation: the amount approved by the legislature must be utilized economically, effectively and efficiently.

5. Periodic: annual or multi-yearly, to predict and plan public sector budget needs.

6. Accurate: budget estimates do not include hidden reserves that cause corruption.

7. Clear: simple and understandable to the public so that it can be watched and criticized by the public.

8. Public knowledge: must be made public.

Based on the explanation above, in the process of public sector budgeting, it is necessary to hold budget integrity through a planning document in the form of a budget that covers the overall budget request and expenditure. This is one of the principles of public sector budgeting in order to clarify the budgeting flow to the evaluation of the budget.

\subsubsection{Public Finance}

In explanation of Law No. 17 of 2003 on State Finance, The approach used in formulating State Finance is as follows:

1. Object. The object referred to as State Finance includes all rights and obligations of the state that can be valued in money, including policies and activities in the fields of fiscal, monetary and management of separated state assets, as well as everything in the form of money, or in the form of goods that can be made as state property by exercising these rights and obligations.

2. Subject. The subject referred to as State Finance covers all objects as mentioned above which are owned by the state, and/or controlled by the Central Government, Regional Governments, State/Regional Enterprises, and other bodies that are related to state finance.

3. Process. The State Financial Process covers the entire set of activities related to object management starting from policy formulation and decision making to accountability.

4. Purpose. The purpose of the State Finance includes all policies, activities and legal relations relating to ownership and/or control of objects as mentioned above in the context of the administration of state government.

In the process of preparing state finances and public sector budgeting, it is necessary to pay close attention to the budget justification. According to John L. Mikesell (2010: 475), the budget justification should consider the following:

1. The justification must avoid jargon and uncommon and unexplained abbreviations because its audience includes individuals less familiar with the details of the proposed activity than the operating agency's personnel. neither budget agency examiners, not legislators are likely to approve poorly described projects. never create your own acronyms. the justification should follow the basic standards of expository writing: short sentences, short words, active voice, no footnotes and eliminate unnecessary words. 
2. The justification must be factual, provide documented sources, and go through ordinary review and revision to produce a polished presentation. some of the justification may be technical; however, the technical parts cannot overwhelm the rest or be left unexplained. the justification has to focus on the small number of points that the reader should pay attention to and remember

3. The justification structure must address the current situation, additional needs, and expected the result from honoring the request. One section of justification should describe the current program in terms of measurable workloads, staffing, funding, or productivity trends. It should briefly and specifically inform the budget examiner's attention. Another section of the justification should describe additional needs. It must specifically identify additional funds, personnel, and materials needed for the budget activity at issue. The reason for the need must be explicitly developed. The examiner must not have to guess what and why

4. The request must indicate what beneficial results will come from granting the request. It must make clear that something important will be made better if the requested activity is carried out and that the agency has the capacity to carry it out.

\subsection{Framework}

As described above, in public finance has organizational goals, in this case, the state/government in achieving its objectives. So in the preparation must be truly adjusted in the current state of the country. The intended preparation is in the form of a The State Revenue and Expenditure Budget (APBN) document compiled based on a mechanism whose authority follows the DPR RI Budget Board, which is a complementary board that has the authority to discuss the preparation of the APBN together with the government. In the preparation process, each budget line is rationalized in order to clarify the direction of the use and use of the budget so as not to cause concern over budget misappropriation.

Based on the above, it is necessary to justify the budget so that it can be approved and used as a means of achieving the country's goals. According to John L. Mikesell, (2010: 475) that in the budget justification must pay attention to the following matters:

1. Avoiding obscure jargon and abbreviations.

2. Justification must be factual by providing data based on reliable and accurate sources.

3. must be able to answer the current problem or condition.

4. The benefits of requests.

The state's objectives summarized in the APBN are things that must be observed by the public so they must be informed to the public. The House of Representatives Budget Agency which is a legislative instrument in the budget formulation is one measure in the formulation of a good APBN where discussions regarding the preparation of the APBN are carried out in the discussion room which is then criticized and ratified. Budget execution is carried out by executives who will be allocated through government programs and evaluated as material for the preparation of the next year's budget. The community as the subject of development has the right to supervise and has obligations in matters of taxation.

The budget preparation, which must cover current needs and conditions. Adjustment of budget allocations illustrates the realization made by the executive 
and provides results as a form of budget effectiveness achieved by the government. Public finance is a form of accountability for the absorption of the budget made by the government during a certain period. In this case, the author becomes the reference of the analysis conducted on the preparation of the State Budget carried out by the government (executive) and the Indonesian Parliamentary Budget Agency (legislative).

\subsection{Proposition}

Based on the framework that has been stated previously, the authors formulate the research hypothesis as follows: The preparation of the APBN by the Indonesian Parliamentary Budget Agency and the Government is carried out to see the accuracy of the budget line through the Budget Justification in order to achieve the objectives.

\section{Research Methods and Objects}

\subsection{Research methods}

\subsubsection{Research methods}

In this study, researchers used a qualitative approach. Qualitative research is one of the research procedures that produces descriptive data in the form of speech or writing and the behavior of the people observed. The qualitative approach was chosen because the purpose of this research is to view the object as a dynamic so it needs to be expressed in depth the meaning of an event, phenomenon, and problem that occurs in people's lives. It is as expressed by Creswell (2014: 4) that qualitative research departs from methods to explore and understand the meaning by a number of individuals or groups of people ascribed to social or humanitarian problems. Then the use of qualitative methods in this study aims to gain an in-depth understanding of the policy formulation of the National Budget in the Indonesian Parliament Budget Agency.

The inductive way of thinking used in the study of the Public Financial Analysis of the National Budget Formulation Policy in the DPR RI Budget Board is a thought process that stems from specific matters to general matters. The qualitative research method uses inductive thinking because in the process of collecting data it emphasizes the use of interviews, observation, and non-statistical analysis. Creswell (1994: 93) states that there are actually no fixed rules for placing theory in qualitative research. However, given the qualitative method of positioning the theory as inspiration and comparison, the function of the theory is maximized in developing interpretation and construction activities during interviews and observations.

\subsubsection{Data Collection Techniques and Research Instruments}

Data collection is done using the method used in a qualitative approach where the researcher himself as an instrument in research. The researcher uses the following data collection techniques:

1. Data on research results obtained directly from the field, through:

a) In-depth interview technique,

b) Observation,

c) Focus Group Discussion (FGD),

2. Secondary Data: is data that is not obtained directly from the field but from contextual ones, such as: 


\section{a) Documentation Study}

b) Literature Study

In qualitative research, as carried out in this study puts researchers as the main instrument of research (human instrument). The direct involvement of a researcher in the object or target under study is a characteristic of research in a qualitative design. By not taking distance from objects/merging, a researcher can master various phenomena and problems in the field. In this study, the researcher himself is a research instrument that is supported by assistive devices such as writing instruments, tape recorders, photos, and maps. The interview material is developed according to the data points needed.

\subsubsection{The Techniques of Informant Determination}

Data sources in this study are primary data sources and additional data sources or secondary data. The informants chosen in this study were informants who involved in the cycle of formulating the APBN Law and also as implementing the APBN, both from the Executive and the legislature. Then in this study also taken from sources selected from parties who have the knowledge and also experience or who have direct involvement in the preparation of the APBN, Then the informants and informants in this study were selected who have a broad understanding of the preparation of the APBN. Then in this study also taken from sources selected from parties who have the knowledge and also experience or who have direct involvement in the preparation of the APBN, Then the informants and resource persons in this study were selected who have a broad understanding of the preparation of the APBN. Selected informants and resource persons are as follows:

Table 1 list of Informants and Research resource persons

No

resource persons

1a

resource persons

$1 \mathrm{~b}$

resource persons

2a

resource persons

2b

informants 1

informants 2

informants 3

Informants 4
Informants

Chairperson of the Indonesian Parliamentary Budget Agency

Director of Budget Preparation, Directorate General of Budget, Ministry of Finance

Member of the Indonesian Parliamentary Budget Agency

APBN working committee members

Member of Commission VII DPR RI

Member of Commission XI DPR RI

Director of the Fiscal Policy Office

Director of Development Funding Allocation Bappenas RI
Amount

1 Person

1 Person

1 Person

1 Person

1 Person

1 Person

1 Person

1 Person 


\subsubsection{Research Location}

The location of the study the authors carried out at the Budget Office of the Republic of Indonesia House of Representatives which is located at Jl. Jenderal Gatot Subroto, Central Jakarta City, Special Capital Region of Jakarta 10270.

\subsection{Object of Research}

The object of research here is the Budget Agency formed by the DPR and is a permanent instrument of the DPR. The DPR determines the composition and membership of the Budget Board according to the balance and equal distribution of the number of members of each faction at the beginning of the DPR membership period and at the beginning of the session year. The composition and membership of the Budget Board consist of members from each commission chosen by the commission after taking into account the balance of the number of members and the proposed faction. The Leadership of the Budget Agency is a leadership unit that is collective and collegial in nature. The Budget Board Chairperson consists of 1 (one) Chairman and a maximum of 3 (three) deputy chairs elected from members of the Budget Agency based on the principle of deliberation for consensus and proportionality by considering the representation of women according to the balance of the number of members of each faction.

A. The Budget Agency has the following duties:

1. Discussing with the Government represented by the minister to determine the principles of general fiscal policy and budget priorities to be used as a reference for each ministry/institution in preparing budget proposals;

2. Determine state revenue together with the Government by referring to the proposal of the relevant commission;

3. Discuss the draft law on the State Budget with the President which can be represented by the minister;

4. Discussing the realization and prognosis reports relating to the APBN; and

5. Discusses the main points of explanation of the draft law on accountability for the implementation of the State Budget.

B. The Budget Board only discusses budget allocations that have been decided by the commission.

C. Commission members in the Budget Agency must work for the budget allocation decided by the commission and submit the results of the implementation of the tasks referred to in paragraph (1) to the commission.

\section{Research Result}

To facilitate the discussion of research results, the authors divide the discussion of chapter four into several main topics, namely: (1) Research results consisting of the characteristics of the DPR RI Budget Board and the compilation of the state revenue and expenditure budget. (2) Discussion of research results based on the results of triangulation and in the form of researcher interpretation.

\subsection{DPR RI Budget Board}

\subsubsection{Characteristics of the DPR RI Budget Board}

The Budget Board is formed by the DPR and is a permanent instrument of the DPR. The DPR determines the composition and membership of the Budget Board according to the balance and equal distribution of the number of members of 
each faction at the beginning of the DPR membership period and at the beginning of the session year. The composition and membership of the Budget Board as referred to in paragraph (1) consists of members from each commission chosen by the commission by taking into account the balance of the number of members and the proposed faction. The Leadership of the Budget Agency is a leadership unit that is collective and collegial in nature. The Budget Board Chairperson consists of 1 (one) Chairman and a maximum of 3 (three) deputy chairs elected from and by members of the Budget Agency based on the principle of deliberation for consensus and proportionality by considering the representation of women according to the balance of the number of members of each faction.

A. The Budget Agency has the following duties:

1. Discussing with the Government represented by the minister to determine the principles of general fiscal policy and budget priorities to be used as a reference for each ministry/institution in preparing budget proposals;

2. Determine state revenue together with the Government by referring to the proposal of the relevant commission;

3. Discuss the draft law on the State Budget with the President which can be represented by the minister;

4. Discussing the realization and prognosis reports relating to the APBN; and

5. Discusses the main points of explanation of the draft law on accountability for the implementation of the State Budget.

Provisions for the continuity of duties of the Indonesian House of Representatives and their position as representatives of legislators to discuss budget plans have been regulated in separate provisions. This was supported by a statement delivered by the Chairperson of the Indonesian Parliamentary Budget Agency through an interview session conducted by the author which stated that:

"As contained in Law No. 17 of 2003 concerning State Finance and MD3 Law, roughly summarizes the tasks of the Budget Agency (Banggar) as follows. Banggar together with the Government was given the task to discuss the State Budget Law until it was decided in the DPR Plenary session. The discussion on the APBN Law starts from preliminary talks, then discusses Macroeconomic Policy (KEM) and Fiscal Policy Principles (PPKF) which serve as a reference for Ministries and Institutions to propose budgets. The President conveyed the Financial Note (NK) and the Draft State Budget, regarding budget allocations for the Government and Regional Transfer Funds by referring to the decision of the working meetings of the commission and the Government. Furthermore, synchronizing the results of discussions in the commission and other DPR fittings regarding the work plan and budget of the ministry/institution. the results of this synchronization later became RUU APBN, until it was decided by the DPR in a plenary session. All these discussions take place in a predetermined cycle of time and discussion ... "

As stated that the House of Representatives Banggar has an important role in the process of drafting the National Budget, to discuss the accountability of the realization of APBN in the fiscal year which in this study is the 2018 Budget Year. Banggar provides an analysis of the budget line and sharpening the budget objectives that have been decided by the commission which is then further discussed with executive representatives in this case the relevant Ministry, the Ministry of Finance. Even though it is full of political elements in making decisions and pulling 
back and forth from the budget, in practice the Budget Agency is one form of legislative independence in the state structure.

\section{A. The Budget Board only discusses budget allocations that have been decided by the commission.}

The Banggar portion in preparing the APBN has been regulated in MD3 Law and the State Finance Law. In this case, Banggar analyzes the budget decided by the commission to be further discussed with the executive based on a predetermined schedule. Practically, Banggar DPR RI does not have significant obstacles in carrying out its duties. That is because all the workloads of Banggar have been regulated by mechanisms in the laws and regulations that involve stakeholders and must be carried out as well as possible without undermining the role of each stakeholder in deciding the budget ceiling to be stipulated in the APBN.

\section{B. Commission members in the Budget Agency must work for the budget allocation decided by the commission and submit the results of the implementation of the tasks referred to in paragraph (1) to the commission.}

The determination of the APBN to be a legal product was delivered by the DPR RI Banggar in a plenary meeting with the executive within a certain period of time. In addition, the DPR RI Banggar will reiterate the accountability of the APBN which had previously been a legal product as stated by the Chairperson of the DPR RI Budget Board in the discussion above. Furthermore, the Budget Agency discusses the APBN from a draft previously decided by the commission, the matter was conveyed by the chairman of the Budget Agency to the author who said that.

In this case, the writer found that there was a long discussion between the commission in the DPR and the executive regarding the determination of the indicative ceiling in the APBN. This is unavoidable due to the point of discussion of the basic macroeconomic assumptions that each stakeholder has a different understanding and prediction in planning for the coming APBN. This is supported by the statement of members of the House of Representatives Commission XI in an interview session conducted by the author that,

"The obstacle that often occurs is when the House of Representatives Commission $X I$ and the Minister of Finance have set Macro Assumptions at the beginning of the APBN Discussion to be used as a reference for the APBN. The budget thus changes State Revenues, State Expenditures, and Deficits."

The author finds that the obstacles that occur between each stakeholder result in a delay in the time of discussion if there is disagreement between parties. In this study, analyzing how the continuity of the preparation of the APBN in order to be ideal after going through long stages and repeatedly conducted discussions. Policy-related decisions are indeed full of political decisions that lead to meeting the needs of every interested party. So in the case of a deadlock discussion, there needs to be a party specifically delegated with authority to be able to justify the decision later which is inseparable from the existing rules.

\subsubsection{Compilation of the State Expenditure Budget}

The State Budget (APBN), is the annual financial plan of the Indonesian government approved by the House of Representatives. APBN contains a systematic and detailed list of planned state revenues and expenditures for one fiscal year (1 
January - 31 December). APBN, APBN changes, and APBN accountability every year are determined by law. Since the enactment of Law No.17 / 2003 on State Finances and Law No.1 / 2004 on State Treasury, the management of the APBN has changed in the budgeting process, from planning to budget execution. The following are the stages of the process of planning and preparing the APBN.

The APBN planning and budgeting process is the first stage in the APBN cycle series. APBN planning and budgeting are carried out one year before the APBN budget year is implemented. The APBN planning stage is the initial phase before the next budgeting process is carried out. In the APBN planning, the direction of policies and national development priorities is compiled, until a Government Work Plan (RKP) and indicative ceiling are set. Whereas the budgeting process starts from the compilation of fiscal capacity which is the material for determining the Indicative Ceiling, to the submission of the Financial Note, the APBN Plan, and the draft APBN law to the DPR.

A. Preliminary stage

1. The initial stage of preparing the draft APBN by the government includes determining the basic assumptions of the APBN, estimated revenues and expenditures, priority scale, and preparing the exercise budget. The basic assumptions of the APBN include:
a. economic growth,
b. inflation rate,
c. rupiah exchange rate,
d. three-month SBI interest rates,
e. international oil prices, and
f. lifting.

2. Holding a commission meeting between each commission with its partners (technical departments/institutions).

3. Conduct the process of finalizing the preparation of the Draft State Budget by the government

B. Stage of submission, discussion, and determination of the APBN

1. This stage began with the president's speech as an introduction to the RUU APBN and the Financial Note.

2. Next, discuss both the finance minister and the DPR budget committee and between the commissions and relevant technical departments/institutions.

3. The results of the discussion in the form of the APBN Law contain budget units as an inseparable part of the Act. Budget unit is a budget document that sets the allocation of funds per department/agency, sector, subsector, program and project/activity.

4. To finance general government and development tasks, ministries/agencies submit Work Plans and Ministries / Institutions Plans (RKAKL) to the Ministry of Finance and Bappenas for later discussion into a Budget Implementation Entry List (DIPA) and verified before the payment process. This process must be completed from October to December.

5. In implementing the APBN instructions are made in the form of a Presidential Decree (Kepres) as a Guideline for APBN Implementation. In carrying out payments, the head of the office/project leader in each ministry and institution submits a request for payment to the State Treasury Regional Office (KPPN). 


\section{APBN Oversight Stage}

1. The oversight function of the implementation of the APBN is carried out by functional supervisors, both external and internal, of the government.

2. Before the end of the fiscal year (around November), the government through the Minister of Finance makes a report.

Accountability for the implementation of the APBN and report it in the form of a State Budget Calculation Bill (RUU PAN) no later than fifteen months after the end of the APBN implementation of the relevant fiscal year. This report is prepared on the basis of the audited realization of the Supreme Audit Board (BPK). If the results of the examination of the calculation and accountability of the implementation as outlined in the RUU PAN are approved by the BPK, the RUU PAN is submitted to the DPR for approval of the State Budget Calculation Law (PAN Law) of the relevant fiscal year.

In every preparation of the APBN, it is indeed inseparable from a political policy. This is particularly felt especially in 2018 and 2019 is a political year that will affect the budget posture. Quoted from one of the website pages investor.id which was published on 30 October 2017 that, responding to the 2018 State Budget, Bhima Yudhistira said, 2018 became a political year so that it affected the APBN.

\subsection{Discussion}

In this discussion, the author will analyze the results of research that has been done based on the theory in the previous chapter. The theory used by the author is the budget justification theory, must pay attention to the four interrelated components. And the problem with this research is that the 2018 Republic of Indonesia National Budget will be effective if the four components described by John L. Mikesell, (2010: 475) are implemented well and longitudinally so that it will reach a form of state administration budget that supports the government. From these statements, the author will describe the results of observations and interviews which the authors compare with the theory of budget justification according to John L. Mikesell, (2010: 475). This is done by looking at the role of each actor or actor involved in the preparation of the state budget, based on the concept of the actor revealed by John L. Mikesell.

\subsubsection{The justification must avoid jargon and uncommon and unexplained abbreviations.}

In the 2018 APBN Information book officially published by the Ministry of Finance of the Republic of Indonesia, an explanation of the terms relating to the $2018 \mathrm{APBN}$ is explained in the glossary section at the end of the page. As for the terms, some of them are as follows:

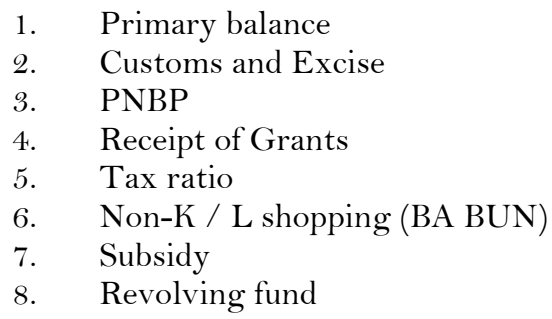


In addition, in the Draft Law of the Republic of Indonesia Number 15 of 2007 concerning the State Budget for the 2018 Fiscal Year, there is a special section on the explanation of the contents of the bill which is explained in detail article by article.

According to the Director-General of Budget, in preparing the APBN there are stages that must be passed starting from: a) Indicative Ceiling in March b) Budget Ceiling in June and c) Allocation Ceiling in December. This stage must be carried out because it is a mandate in the Law on State Finances, so that in preparing the APBN it is naturally reasonable to avoid tugging assumptions that can result in delays in the discussion agenda for the preparation of the APBN, while what often becomes an obstacle is the timing of the submission of APBN documents in each stage of APBN preparation. The finding of the obstacle was conveyed by Member of commission XI who said that,

"The obstacle that often occurs in discussions of the APBN with the Government is the data problem. Commission XI of the DPR gets more data from the Government and usually, the data obtained from the Government is given before the APBN discussion so there is not much time to check the data provided by the Government."

Therefore, the DPR which has the oversight function should be able to optimize the time in terms of the submission of APBN documents because the delay in the preparation stage of the APBN greatly impedes the performance of stakeholders involved in the preparation of the APBN.

\subsubsection{The Justification Must Be Factual}

This section talks about how to provide documented resources, and through regular reviews and revisions to produce a good presentation. Financial projections as a form of fiscal policy are an integral part of an organization's planning and control system. In this case, Ministries / Institutions need financial projections in order to be able to predict future conditions effectively. Through these predictions, management can make the right decisions for future developments.

In every preparation of the state budget, factual information is needed that is supported by the latest data and can be accounted for. This is certainly supported by one of the performances of Bank Indonesia's involvement in the preparation of the APBN which has historically provided information and exposure related to macroeconomics, inflation and exchange rate developments that are closely related to the posture of the APBN the following year. This was stated by a Member of the Board of Governors of Bank Indonesia through an interview conducted by the author, that;

"The preparation of the APBN involves Bank Indonesia in the presence of the Governor of Bank Indonesia / other members of the Board of Governors. The presence of $G B I / A D G$ is supported by various related work units at Bank Indonesia. The role of Bank Indonesia is expected to provide a view on macroeconomics, specifically economic growth, inflation and the exchange rate, which is very closely related to the task area of Bank Indonesia."

The Budget Agency in charge of conducting the discussion reviews the submission of the RUU APBN that has been decided by the commission. The changes that have taken place by the Banggar of the Republic of Indonesia House of Representatives in order to form a factual and convincing indicative ceiling of the 
Draft State Budget. As stated by Bank Indonesia, the rupiah exchange rate greatly influences the determination of the budget, so Banggar must really make updates and predictions of the rupiah exchange rate. Changes in the exchange rate of the rupiah, even though only Rp.100, but have a big effect on each set of budget items. So this debate has become very difficult to equate macro assumptions in the preparation of the APBN. All this time the discussion about macro assumptions has been completed in the commission chambers, but the discussion on macro assumptions has often been tough. So far, no one can take over when there is a deadlock between the commission and the government. The deadlock caused the discussion in the commission to be extended, so this became a weak point. Here the role of DPR RI of Banggar can be granted more authority related to macro assumptions so that the determination of the budget line can be in accordance with the needs of the people and the discussion conducted between stakeholders involved in the preparation of this APBN can be carried out more efficiently.

\subsubsection{The Justification structure must address the current situation, additional needs, and expected results from honoring the request.}

Then according to John L. Mikesell, (2010: 475), the justification structure must describe the current program in terms of measurable workload, staffing, funding, or productivity trends. Other parts of the justification must explain the additional needs. It must also be able to identify additional funds, personnel, and materials needed for the budget activities in question. The reasons for this need must be developed explicitly so as not to raise the question of what or why.

In the last four years, the APBN has been optimally supporting quality economic growth. The poverty rate was successfully reduced from 11.25 percent in March 2014 to 9.66 percent in September 2018. In the same period, the Gini ratio or the level of income inequality of the people also dropped from 0.406 to 0.389 . This shows that the welfare distribution in the community has gradually improved. It is hoped that the income gap between the lower-middle-class and upper-middle-class will decrease even smaller in the following years. Meanwhile, the open unemployment rate (TPT) has decreased from 5.70 percent in February 2014 to 5.34 percent in August 2018.

In the midst of the global economic challenges that are not easy, the performance of the $2018 \mathrm{APBN}$ also shows very encouraging achievements. For the first time since 2011 , the realization of state revenues has exceeded the target set in the state budget (102.5 percent). The realization of state revenues in 2018 reached 1,942.3 trillion or grew by 16.6 percent, higher than the growth in 2017 which reached 7.1 percent. Sources of state revenue are still dominated by tax revenue which reached Rp 1,315.91 trillion (92.41 percent of the 2018 APBN) or grew 14.32 percent from the realization of the 2017 APBN.

The realization of K / L expenditure up to December 31, 2018, reached Rp 836.2 trillion or 98.68 percent of the 2018 APBN ceiling. This realization was higher than the realization of $\mathrm{K} / \mathrm{L}$ spending in the same period in 2017.

The factors that influence the level of absorption of K / L spending in 2018 include the continuation of the policy acceleration of the implementation of activities through early auctions, distribution of social assistance, and the implementation of several strategic agendas such as the Simultaneous Local Election, the implementation of the Asian Games in Jakarta and Palembang, and Asian Para Games in Jakarta. In addition, the performance of absorption of K / L expenditure 
is also influenced by the additional support for spending on additional strategic activities, such as activities related to handling natural disasters that occurred in 2018, strengthening bureaucratic reforms in K / L and support for other urgent needs.

The budget absorption performance is also followed by the performance of achieving outputs that are clearly felt by the community. In the field of infrastructure (Ministry of PUPR and Ministry of Transportation) construction of $630 \mathrm{~km}$ of roads, 7,673.2 $\mathrm{m}$ of bridges has been completed, construction of 4 airports and 4 new airports, and $452.9 \mathrm{~km}$ of railway development. In the field of Education (Ministry of Education and Culture, Ministry of Religion, and Ministry of Research, Technology and Higher Education) distribution of Indonesia Smart Cards for 19.8 million students, distribution of school operational assistance to 8.7 million students, and distribution of Bidik Misi scholarships to 392.0 thousand students. In the field of Health and Social Protection (Ministry of Health and Ministry of Social Affairs), the distribution of the Indonesia Sehat Card has been carried out to 92.3 million beneficiaries, and the distribution of hopeful family programs for 9.9 million beneficiary families, as well as non-cash food assistance for 15.2 million families.

Meanwhile, the realization of non-K / L expenditure in 2018 reached Rp 608.23 trillion or reached 100.19 percent of the 2018 APBN ceiling. Factors affecting the level of non-K / L spending include: (1) payment of debt interest of IDR 258.09 trillion and subsidy of IDR 216.77 trillion, where the realization of debt interest payment is influenced by the depreciation of the Rupiah against the US Dollar; and (2) subsidy realization reached Rp 216.77 trillion which was influenced by changes in ICP assumptions and the Rupiah exchange rate against the US Dollar, settlement of underpayments of energy subsidies in the previous year, policies to adjust diesel subsidies from 500 / liter to 2000 / liter as an effort to absorb the risk of price increases that can reduce people's purchasing power and control inflation. The absorption and realization of non-K / L expenditure are also influenced by the THR payment policy for pensioners and the disbursement of JKN program reserve funds to cover the DJS Health deficit. The absorption rate of non-K / L spending is higher than the absorption rate in 2017.

Table 2. Realized APBN outlook 2017 and 2018

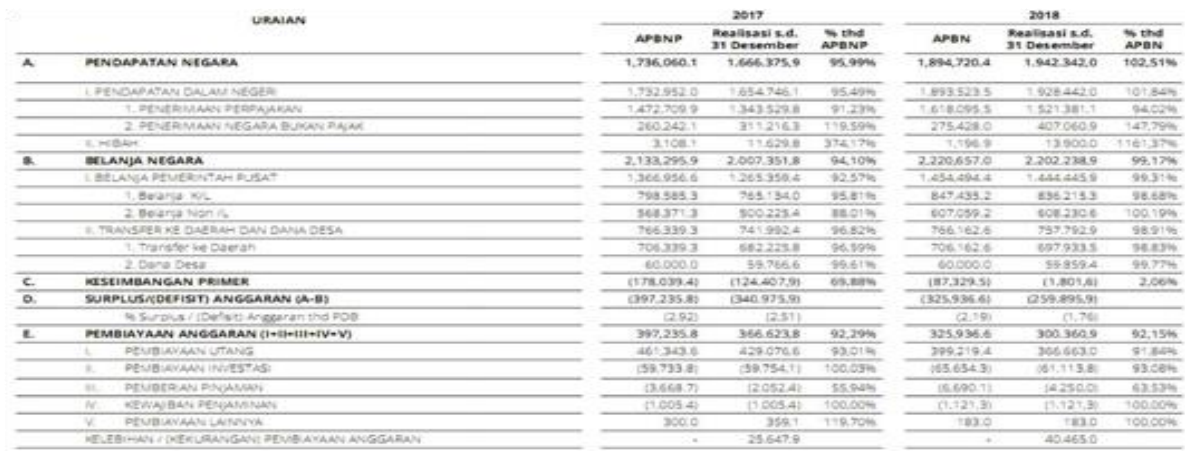

Source: Realized State Budget until 31 December 2017 and 2018. Source of KITA APBN January 2019 Edition.

From the image of the realization of the APBN in 2017 and 2018 there is a difference in the realization wherein 2017 the realization of this APBN only touched 95.99\% while in 2018 this realization exceeded the target planned by the 
government namely at 102.51 excess from realization in 2018 and the lack of achievement in 2017 this should be a matter that must be considered by the DPR because the ideal plan and realization should be in accordance with no less and no more. So in this case, the role of the Banggar must be able to have more authority in determining budget members because this is very influential in the formation of the APBN structure.

\subsubsection{The request must indicate what beneficial results will come the granting the request form.}

In the last part according to John L. Mikesell, (2010: 475) which needs to be considered is, demand must show what benefits will come from giving requests. It must be clear that something important will be better if the activity requested is carried out and that the institution has the capacity to carry it out. In terms of tax revenue performance, 2018 was a pretty encouraging year. Throughout 2018, the Directorate General of Taxes (DJP) was able to collect Rp 1,315.93 trillion, or 92.41 percent of the Rp 1,424.00 trillion targeted in the 2018 APBN. This achievement in 2018 is the highest in the last five years. If the tax amnesty receipts in the first quarter of 2017 were excluded from the calculation (constituting one-off / nonrecurring revenues of $\mathrm{Rp} 12.03$ trillion), the growth of tax revenue would reach 15.53 percent yoy.

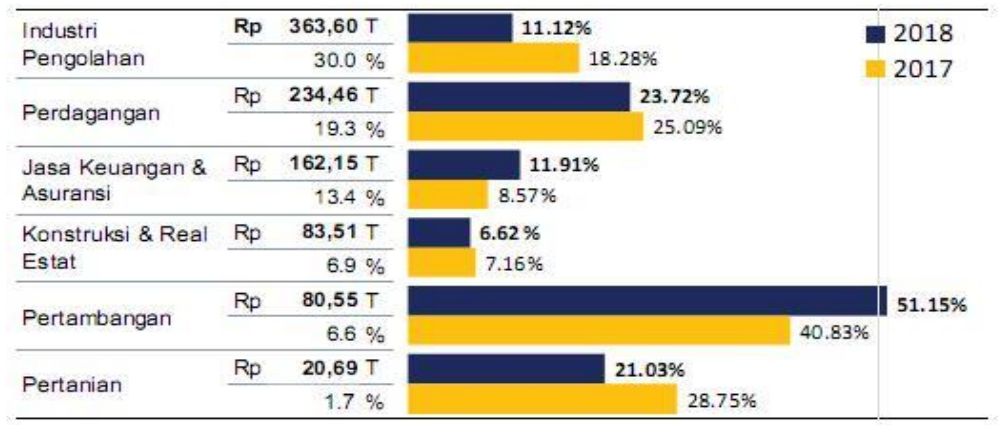

Figure 3. Development of Tax Revenue Source: APBN Kita January 2019 Edition

From a sectoral perspective, throughout 2018 the main business sectors were able to maintain double digits tax revenue growth. The Manufacturing Industry sector grew 11.12 percent yoy, Trade grew 23.72 percent yoy, and Financial Services and Insurance grew 11.91 percent yoy. Mining grew 51.15 percent yoy, still influenced by the upward trend in mining commodity prices. Agriculture grew 21.03 percent yoy, while Construction and Real Estate were still able to grow 6.62 percent.

The description above is a form of budget realization compiled by the executive. This is inseparable from the role of the DPR RI in charge of delivering discussions and also being responsible for the agreed APBN implementation report. the ongoing cycle, at the stage where the APBN has been running, the DPR RI of Banggar as one of the important role holders in the preparation of the APBN documented the realization of the APBN so that it could then be used as material for further RAPBN discussion. 
However, the preparation of $2018 \mathrm{APBN}$ is basically inseparable from political interests, this is related to the position of the DPR which is represented by the DPR RI Budget Agency is a representative of the legislature who has a political role as a form of people's sovereignty. In the end, every organization that has an interest in discussing the Draft APBN (R-APBN) must coordinate the needs of each budget line that is structured in the indicative ceiling to be able to realize its interests. The debate that often occurs in the writer's observation on the process of drafting the APBN Draft generally occurs when discussing the basic macroeconomic assumptions.

\section{Conclusions and Suggestions}

\subsection{Conclusions}

Based on the results of research on the analysis of Public Finance in the preparation of the State Budget (APBN) of the Republic of Indonesia in 2018, it can be concluded The existence of a time delay in the realization of the discussion schedule for the Draft Bill on the 2018 APBN has affected the existing cycle. This is influenced by the attraction of interests that cannot be avoided in work meeting activities, ranging from group interests to individual interests.

The preparation of the 2018 State Budget includes various stages including (1) the preliminary stage; (2) the stage of filing, discussing and determining the APBN; and (3) the APBN oversight phase. The preparation of the APBN 2018 involved various parties consisting of the DPR RI Budget Board, the Ministry of Finance, Bappenas and other technical ministries, and Bank Indonesia (BI) as the country's monetary authority which provided input mainly related to determining the inflation target and the rupiah exchange rate and other monetary policies. The Regional Representative Council (DPD) is also involved in providing input on the APBN. Local government and experts or experts are also involved in seeking input in every discussion of the APBN.

In the discussion of the APBN 2018 based on a bill decided by Commission VII of the DPR RI, it can be said that there are no terms or abbreviations that are multi-interpreted and can be understood by the general public. Then in the preparation of the APBN in each discussion, data and factual conditions are needed to be able to predict the strategies that will be contained in the APBN. The documented data must factually answer the challenges in the next financial year.

The APBN 2018 shows positive results in achieving various strategic output targets that support Indonesia's economic growth. This can be seen from the performance of the absorption of the 2018 budget in various fields where the achievement of output is felt significantly by the public, such as; in the field of infrastructure, construction of roads, bridges, airports, and railroads has been achieved. in the field of education, the distribution of the Smart Indonesia Card for 19.8 million students has been carried out, the distribution of school operational assistance to 8.7 million students, and the distribution of Bidik Misi scholarships to 392.0 thousand students; and in the field of Health and Social Protection the distribution of the Indonesia Sehat Card has been distributed to 92.3 million beneficiaries, and the distribution of hopeful family programs for 9.9 million beneficiary families, as well as non-cash food assistance for 15.2 million families.

Tax revenue achievements in 2018 have exceeded the 2018 State Budget target. Throughout 2018, the Directorate General of Taxes (DJP) was able to collect Rp 1,315.93 trillion, or 92.41 percent of the Rp 1,424.00 trillion targeted in the 2018 
State Budget. Customs and excise revenue alone increased 7.8 percent compared to the target in the 2017 APBN / P. The achievement of these targets is inseparable from the role of the government which also tried to overcome the effects of the trade war, as well as improving various policies.

\subsection{Suggestions}

Based on the unit of analysis and the findings of the author during the study, the authors provide suggestions for consideration, as follows:

1. In the process of filing the RUU APBN, the executive is not too late in providing documents to be discussed so that there is sufficient time for discussion needs. In the process of drafting each APBN, it cannot be separated from political interests, so that the discussion will be very difficult to find an agreement and slow down the drafting process, so the Budget Agency established as a tool for completing the APBN discussion is given the authority to decide on such disputes.

2. There needs to be a change back in the MD3 Law which contains the delegation of authority to the Budget Agency to be given duties and authority in order to resolve disputes and reduce political interests therein. That is because the Budget Agency is the recipient of budget decisions given by the commission and which discusses each line item submitted by the executive as a regulated mechanism. Even so, it will not make the Budget Agency a superpower in the preparation of the APBN but must conduct discussions in a fair, logical and visionary manner.

3. The DPR RI Budget Board consisting of members of the DPR at least has its own research team, prepared to collect factual data as one of the bases for justification of the budget items to be discussed. Coordination between the Director-General of the Ministry of Finance's Budget and the Indonesian Parliament's Budget Agency must be strengthened by the existence of a clear coordination meeting schedule and does not lead to protracted schedule delays.

\section{References}

Aidan R. Vining and David L. Weimer, "Informing Institutional Design: Strategies for Comparative Cumulation," Journal of Comparative Policy Analysis 1:1 (1998), 39-60.

Agus Dharma. 2001. Manajemen Supervisi. Jakarta: Raja Grafindo Persada.

Atmosudirdjo, P. 1990. Dasar-Dasar Ilmu Adminintrasi. Jakarta: Ghalia Indonesia.

Bungin, Burhan. 2009. Metodologi Penelitian Kualitatif. Jakarta: Kencana. Predana Media.

Dunn, William N. 2000. Pengantar Analisis Kebijakan Publik, cet. ke-IV. Yogyakarta: Gajah Mada University Press

Dunn, William N. (2003). Analisis Kebijakan Publik. Yogyakarta: Gadjah Mada. University Press.

Dwijowijoto, Riant D. 2004. Kebijakan Public Formulasi, Implementasi Dan Evaluasi. Jakarta: PT. Elex Media Komputindo.

Dwiyanto, Agus. (1995). Mewujudkan Good Governance Melalui Pelayanan Publik. Yogyakarta:Gadjah Mada University Press

Dye, Thomas R. 1978. Understanding Public Policy. Engelwood Cliffs : Prentice Hall

Friedrick, Carl J. 1963. Man and His Government. New York: Mc Graw Hill

Handayaningrat, Soewarno. 1993. Pengantar Studi Ilmu Administrasi dan Manajemen. Jakarta: CV. Gunung Agung.

The Indonesian Journal of Development Planning

Volume III No. 2 - August 2019 
Islamy, M. Irfan, . 2000. Prinsip-Prinsip Perumusan Kebijakan Negara. Jakarta : Bumi Aksara

Mahsun, Mohamad, 2006. Pengukuran Kinerja Sektor Publik,. Penerbit BPFE, Yogyakarta.

Mardiasmo. 2004. Otonomi dan Manajemen Keuangan Daerah. Yogyakarta.

Mustopadidjadja. 2003. Manejemen Proses Kebijakan Publik.Jakarta :Lembaga Administrasi Negara dan Duta Pertiwi Fundation.

Nugroho, Riant. 2004. Kebijakan Publik, Formulasi, Implementasi. Jakarta : PT.Elex Media Komputindo.

Putt, Allen D. dan J. Fred Springer, 1989. Policy Research; Concepts, Methods, and Application. New Jersey: Prentice Hall.

Siagian, H.,1997, Manajemen Suatu Pengantar, Alumni Bandung

Steers, M Richard. (1985). Efektivitas Organisasi Perusahaan. Jakarta: Erlangga.

Sugiyono. 2007. Metode Penelitian Administrasi. Bandung: CV. Alfabeta.

Sumaryadi, I Nyoman. 2005. Efektivitas Implementasi Kebijakan Otonomi Daerah. Jakarta : CV Citra Utama.

Suryaningrat, Bayu. 1989. Perumusan Kebijakan dan Koordinasi Pembangunan di Indonesia. Jakarta: CV. Bina Aksara.

Thoha, Miftah. 2002. Dimensi-Dimensi Prima Ilmu Administrasi Negara. Jakarta: PT. Raja Grafindo Persada.

Van Meter, Donald S. \& Van Horn, Cark E. 1975. The Policy Implementation Process: A conceptual Framework, Administration \& Society, Vol.6 No4, February 1975.

Wahab, Solichin Abdul. 1998. Analisis Kebijakan dari Formulasi ke Implementasi Kebijakan Negara. Jakarta: Bumi Aksara.

Wahab, Solichin Abdul. 2008. Pengantar Analisis Kebijakan Publik. Malang:UPT Penerbitan Universitas Muhammadiyan Malang.

Winarno, Budi. 2007. Teori dan Proses Kebijakan Publik. Yogyakarta : Media Presindo.

Winter, Soren C. (2003), “Implementation”, (Section 5) In Handbook of Public 